\title{
Roman marble from Lusitania: petrographic and geochemical characterisation
}

\author{
Devi Taelman ${ }^{\mathrm{a}, *}$, Marlina Elburg ${ }^{\mathrm{b}, \mathrm{e}}$, Ingrid Smet ${ }^{\mathrm{b}}$, Paul De Paepe ${ }^{\mathrm{b}}$, Luís Lopes ${ }^{\mathrm{c}, \mathrm{d}}$, Frank Vanhaecke ${ }^{\mathrm{f}}$, \\ Frank Vermeulen ${ }^{\mathrm{a}}$ \\ a Department of Archaeology, Ghent University, Sint-Pietersnieuwstraat 35 - UFO, 9000 Gent, Belgium \\ ${ }^{\mathrm{b}}$ Department of Geology and Soil Science, Ghent University, Krijgslaan 281 - S8, 9000 Gent, Belgium \\ ${ }^{c}$ Department of Geosciences, University of Évora, Rua Romão Ramalho 59, 7000-671 Évora, Portugal \\ ${ }^{\mathrm{d}}$ Geophysics Centre of Évora, FCT, Rua Romão Ramalho 59, 7000-671 Évora, Portugal \\ e School of Geological Sciences, University of KwaZulu-Natal, Private Bag x 54001, 4000 Durban, South Africa \\ ${ }^{\mathrm{f}}$ Department of Analytical Chemistry, Ghent University, Krijgslaan 281 - S12, 9000 Gent, Belgium
}

\section{A R T I C L E I N F O}

\section{Article history:}

Received 18 November 2011

Received in revised form

4 December 2012

Accepted 9 December 2012

\section{Keywords:}

Marble

Estremoz Anticline

Portugal

Roman

Petrography

Strontium isotopes

Provenance

\begin{abstract}
A B S T R A C T
This paper reports the results of an archaeometric study of the marble from the Estremoz Anticline, Portugal. Thirty-four samples from eleven different locations were analysed petrographically. In addition, ten samples were selected for trace element and strontium isotopic analysis. The sampling was aimed at obtaining material from known ancient quarries and at establishing the overall petrographic and geochemical variation of the marble from the Estremoz Anticline. The main type of marble in Estremoz is a white(-veined), calcitic marble with an average maximum grain size between 0.81 and $3.50 \mathrm{~mm}$. ${ }^{87} \mathrm{Sr} /{ }^{86} \mathrm{Sr}$ values of marble leachates range from 0.70850 to 0.70891 and are similar to the results for other Palaeozoic marbles of the Iberian Peninsula.

In addition, a workflow is proposed for distinguishing Estremoz from non-Estremoz marble. For this, the Estremoz marble signature is compared to that of other known Roman marbles of the Iberian Peninsula (Viana do Alentejo, Almeria group, Malaga group, and Almadén de la Plata), as well as to that of the principal classical marbles from the Mediterranean (Carrara, Paros, Naxos, Pentelikon, Hymettos, Dokimeion, Thasos, Aphrodisias and Proconnesos).
\end{abstract}

(c) 2013 Elsevier Ltd. All rights reserved.

\section{Introduction}

Since the modernisation of the quarrying industry in the 1970s, the marble production and export in Portugal has increased exponentially. Nowadays, Portugal is ranked 5th in Europe and 10th in the world regarding ornamental stone production. Around $50 \%$ of these stones are high-quality white and coloured marbles from the Estremoz and Vila Viçosa region (Casal Moura, 2007). Already in Roman times, the potential of this area for marble production was known; recent studies have proven that the marbles were extensively used from the 1st century CE onward in Roman Hispania and in other parts of the western Roman world (Alvarez Pérez et al., 2009; Antonelli et al., 2009; Cisneros Cunchillos, 1988, 1997;

\footnotetext{
* Corresponding author. Tel.: +32 93310164; fax: +32 93310297.

E-mail addresses: Devi.Taelman@UGent.be (D. Taelman), Marlina.Elburg@ UGent.be (M. Elburg), Ingrid.Smet@UGent.be (I. Smet), Paul.Depaepe@UGent.be (P. De Paepe), lopes@uevora.pt (L. Lopes), Frank.Vanhaecke@UGent.be (F. Vanhaecke), Frank.Vermeulen@UGent.be (F. Vermeulen).
}

Cisneros Cunchillos et al., 2010-2011; Lapuente, 1995, 1999; Lapuente and Blanc, 2002; Lapuente and Turi, 1995; Lapuente et al., 2000; Lopes et al., 2000; Morbidelli et al., 2007; Peixoto Cabral et al., 1992).

In this paper, a petrographic and geochemical overview of the Estremoz marble is presented. For this, a multimethod approach was adopted, combining petrographic examination and strontium $(\mathrm{Sr})$ isotopic analysis. Given that previous archaeometric studies have mainly focused on marbles from the central (Italy) and eastern Mediterranean (Greece and Turkey), the present work provides an important update on the petrographic and geochemical knowledge of ancient marbles. In particular, new $\mathrm{Sr}$ isotopic data is presented that can be used for future artefact provenance studies. Moreover, the ${ }^{87} \mathrm{Sr} /{ }^{86} \mathrm{Sr}$ data enlarge the $\mathrm{Sr}$ isotopic composition reference database for ancient marbles, thus improving the use of this parameter for provenance studies. In conclusion, the Estremoz marble signature is compared with that of other known Roman marbles of the Iberian Peninsula (Viana do Alentejo, Almeria group, Malaga 